\title{
PALAEO-GEOGRAPHIC CHANGES IN THE SĀRNATE FORMER LAGOON AREA
}

\section{Paleoǵeogrāfisko apstākḷu pārmaiṇas Sārnates bijušās lagūnas teritorijā}

\author{
Laimdota Kalniņa, Aija Ceriña, Valdis Bērziņš \\ University of Latvia, Faculty of Geography and Earth Sciences \\ Laimdota.Kalnina@lu.Iv
}

\begin{abstract}
Due to the lowering of the Littorina Sea level before approximately 5000 years, Sārnate lagoon was separated from the sea and became a shallow lagoon lake, which gradually terrestrialised and filled in with peat. The aim of the research project reported in this paper was to characterise the changing palaeogeographical conditions in the former Sārnate lagoon area, as recorded by changes in sediment properties, pollen and plant macro-remain composition. The plant macro-remain and pollen studies indicate intensive human activity in the area during the latter part of the Holocene climatic optimum and the first part of the Late Holocene, Subboreal, including a record of Water chestnut (Trapa natans) fruits and pollen in the gyttja under the grass peat, indicating that water chestnut grew in the lake adjacent to the settlement. The presence of cereal and weed pollen confirms that agriculture was also being practiced, at least during the final phase of occupation, in the late 6th and the 5th millennium BP.
\end{abstract}

Keywords: Littorina, gyttja, peat, pollen, plant macro-remains, water chestnut

\section{Introduction}

The Sārnate, former lagoon area, located in the Coastal Lowland belt near the open Baltic Sea coast of western Latvia (Figure 1) has been influenced by various geological processes in different developmental stages of the Baltic Sea. Due to the lowering of the Littorina Sea level approximately before 5000 years, the lagoon was separated from the sea, turning the former lagoonal area into a lake basin, which became overgrown and developed into Sārnate Mire (Mūrniece et al. 1999; Kalniņa et al. 2011). This area is interesting not only in terms of geology and Baltic Sea development, but also from the perspective of archaeology. Thus, the wetland settlement site of Sārnate, located within this area, constitutes one of the richest sources of information concerning human lifeways in the East Baltic during the period approximately 5900-5000 BP, i.e., corresponding in climatic terms to the early part of the Late Holocene (Bērziņš 2008).

Silt and silty sand with a small amount of organic matter was deposited in the area of the present-day Sārnate Mire during the Younger Dryas (12 900 cal. years BP), with the fall in the level of the Baltic Ice Lake. During the Ancylus Lake stage the area contained one or more shallow coastal lakes, which were cut off from the open water of the lake on the western side by a narrow (0.3-0.5 km wide) spit of land (Grinbergs 1957; Veinbergs 1996). Freshwater lime accumulated in some parts of the Sārnate lake, and thin layers of peaty gyttja were formed on their shores. During the Littorina Sea transgression, at the beginning of the Holocene climatic optimum, sea water entered the low-lying area in the environs of Sārnate and other stretches of the coastline with lower topography, and reached a height above present sea level of 5-6 m. This formed a large, 
shallow lagoon, which was cut off from the sea through the process of long-shore drift. The water level during the Littorina regression fell and the lagoon rapidly divided into separate lakes, which became overgrown, and mires were formed (Mūrniece et al. 1999).
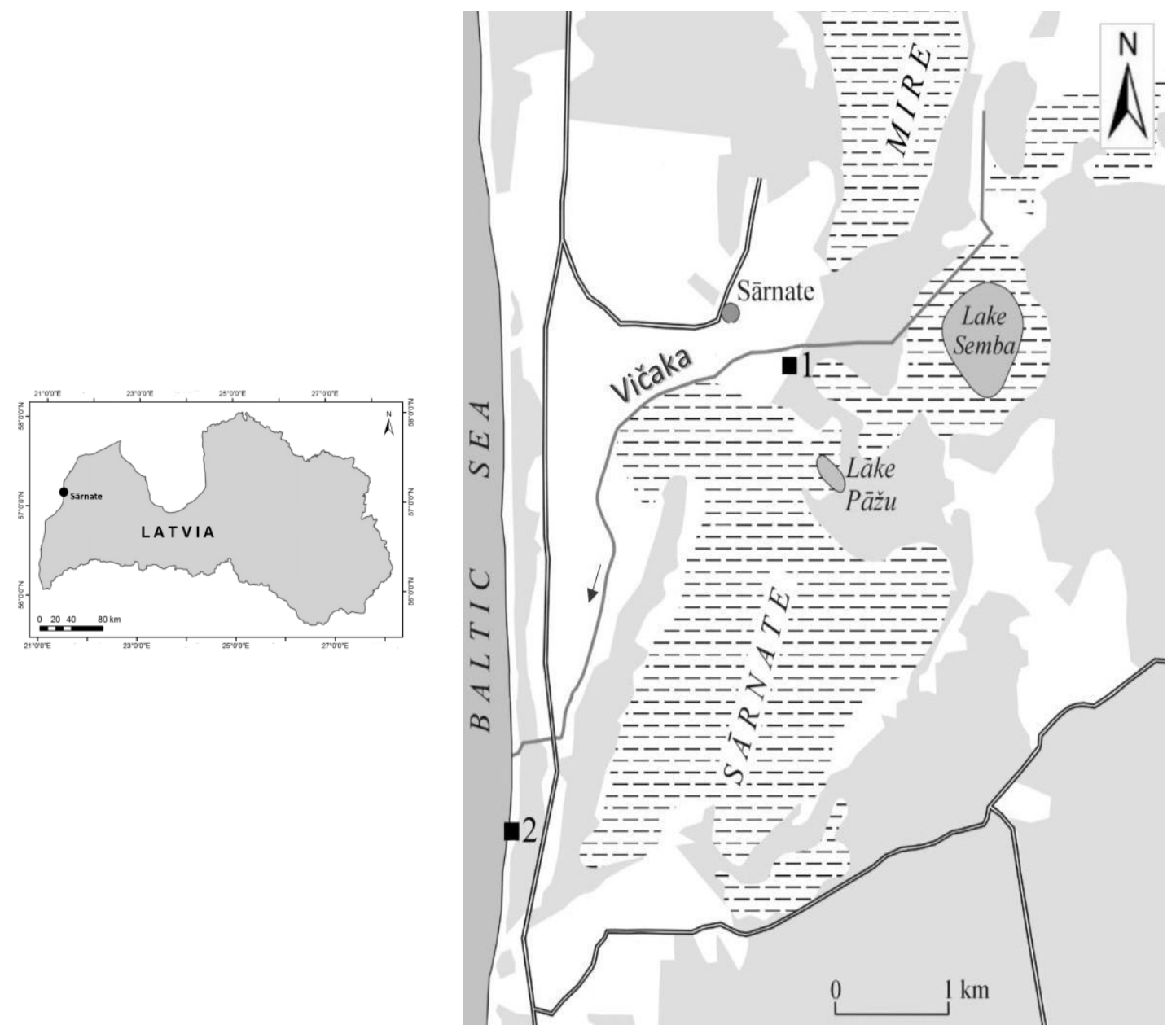

Figure 1. Location of study sites. 1 - Sārnate Neolithic site (Lat. N 57.108988882; Long. E 21.4559243) and core Sārnate IX (Lat. N 57.108 3979; Long. E 21.4582771); 2 - Outcrop at the Baltic Sea Bluff between the rivers Vičaka and Pāžupīte (Lat. N57.0714669; Long. E 21.4155118) (authors' figure)

The occupation of the Sārnate archaeological site falls in a period after the Littorina Sea regression (Mūrniece et al. 1999). Records from the lagoon, lacustrine and bog sediments at Sārnate can be used to trace the changes after the maximum of the Littorina transgression. The first palynological studies at Sārnate lagoon area and the archaeological site were done by A. Dreimanis (1947). Later, detailed pollen analysis was undertaken by M. Galeniece (1960) and D. A. Agranova (Doluhanov 1977). The first information about the large amount of Trapa fruits collected by StoneAge man in the Sārnate Bog settlement is described by E. Šturms (1940).

Water chestnut fruits were also found in the settlement site during the excavations conducted by L. Vankina (Vankina 1970). Samples collected during this excavation from Dwelling O of the Sārnate archaeological site were later analysed by 
complex plant macro-remain analysis (Ceringa et al. 2013). Plant macro-remains have been studied in the sediment sequence from the north-western edge of Dwelling $\mathrm{O}$, where charred plant remains were found in the cultural layer at the top of the sequence. It was revealed that the dwelling had been established on a lacustrine gyttja layer with remains of aquatic plants: yellow water-lily Nuphar lutea, water chestnut Trapa natans and common club-rush Scirpus lacustris (Cerina et al. 2013).

The aim of the research reported in this paper is to characterise the changing palaeo-geographical conditions in the former Sārnate lagoonal area, as recorded by changes in sediment properties, pollen and plant macro-remain composition.

\section{Data and Methods}

The study presented in this paper is based on the results of investigations at three points in the Sārnate former lagoon area: 1) sediment samples from the core Sārnate IX (Lat. N 57.1083979; Long. E 21.4582771), taken at the margin of the present-day Sārnate Mire, immediately south-east of the central part of the archaeological site ; 2) samples of sand from the hearths of Dwelling $\mathrm{K}$ and Dwelling 11 of the archaeological site (Lat. N 57.10898882; Long. E 21.4559243), and 3) samples from organic sediment layers formed in the Sārnate lagoonal area during the Holocene and nowadays revealed at the Baltic Sea bluff between the rivers Vičaka and Pāžupīte (Lat. N 57.0714669; Long. E 21.4155118) due to coastal erosion.

Sampling: Sampling has been performed using recommended approaches for sediment core sampling (Berglund and Ralska-Jasiewiczowa 1986). Coring and sediment sampling were undertaken using a soft sediment sampler with $50 \mathrm{~cm}$ long camera with diameter $7 \mathrm{~cm}$. The sediment monoliths were placed in a special cartridge and wrapped in poly-ethylene film to preserve natural moisture, brought to the laboratory and sliced into $5 \mathrm{~cm}$ intervals. The outer margins were systematically discarded, as these could have been contaminated during sampling.

Plant macro-remain analysis: Plant macro-remains have been extracted and identified from two bulk (volume 11) sediment samples of sand with charcoal fragments recovered during the excavation conducted by L. Vankina and stored at the National History Museum of Latvia: 1) a sample from the hearth of Dwelling K (1949 excavation), belonging to the final phase of occupation, c. 5580-4800 BP; and 2) a sample from the hearth of Dwelling 11 (1959 excavation), with non-diagnostic archaeological remains, not attributable to a particular phase. The overall site plan, showing the location of the dwellings, can be viewed in the publication by V. Bērziņš (2008: 61). In the case of the sediment samples from the outcrop north of the mouth of the Pāžupite, the material from the sediment sequence was divided into 10 subsamples and used for plant macro-remain analysis. The volume of each sub-sample was approximately $200 \mathrm{ml}$. Preliminary processing of the plant macro-fossil samples was undertaken in the laboratory, using flotation to separate the light fraction (flot), collected on a $0.25 \mathrm{~mm}$ sieve, from the heavy fraction (residue). Recovery and 
determination of the plant remains and other sub-fossil remains was then undertaken. The samples for plant macro-remain analysis were prepared following standard techniques (Warner 1990). Plant macro-remains were identified using available reference material, as well as pictures and descriptions in Velichkevich and Zastawniak (2006; 2008).

\section{Results}

\section{Samples from Dwelling 11 and Dwelling K of the Sārnate archaeological site}

A large number of macro-remains, predominantly charred, such as fruits of Trapa, Corylus, as well as seeds of Nuphar lutea Scirpus lacustris, Chenopodium alba and Fragaria vesca, have been found in the samples of sands from the archaeological excavation of the hearths (Dwelling 11 and Dwelling K). The sediment of the hearth of Dwelling 11 contained fruits of Trapa natans (200 fragments), Corylus avellana nut fragments (46), one Pinus sylvestris pine cone scale fragment, a fragment of Poacea (charred grain fragment), Nuphar luteum (charred seed) and Scirpus lacustris ( 2 seeds).The sample from the hearth of Dwelling K predominantly contained achenes of sedges Carex sp. (14) and common club-rush, Scirpus lacustris (19). Seeds of other plants were present in small numbers: Chenopodium album - three nutlets, a few seeds of aquatic plants Potamogeton perfoliatus (1) and Nuphar luteum (1), as well as achenes of Polygonum aviculare, Galeopsis ladanum, Fragaria vesca and Potentilla anserina. The Potamogeton seed is not charred, while the rush and sedge seeds are only partly charred. Most of these plants were used for food.

\section{Core Sārnate IX, at Sārnate Neolithic site}

Records from the lower part of the sequence show the presence of a Hypnum peat layer formed on sandy sediments earlier than 9670-9290 BP, when the depression of the former Sārnate Lagoon was almost dry, with some wet areas providing favourable conditions for Hypnum moss growth. The peat was covered by calcareous clay, which accumulated in a basin, evidently during the maximum Littorina Sea transgression. At a depth of 2.0-2.4 m from the section top calcareous clay with organic remains was deposited, earlier than 8050-7810 BP, when the water level in the basin fell somewhat and the clay became richer in plant and faunal remains. Higher up in Sārnate core IX, at a depth of 2.0-0.85 m, peaty gyttja was laid down. The water level in the basin gradually decreased and the lagoonal lake was progressively filled in and covered by wood-grass fen-type peat. Analysis of the earlier pollen studies data (Kalnina et al. 2011) reveals their composition from sediments of core IX and is used for description of vegetation changes in the surroundings of the Sārnate site starting from the second half of the Early Holocene Boreal, when a pine forest was distributed on sandy soils in the area (Kalnina 2018). Pollen composition at the base of the core, in the depth interval 3.25-3.65 $\mathrm{m}$ from top, represented by the Hypnum peat layer, is characterised by a dominance of birch Betula, a small amount of pine Pinus pollen and herb pollen, mainly represented by 
Poaceae and Cyperaceae. From this time onwards, until the present day, the Sārnate area has been characterised by an open landscape. Pollen composition in the calcareous clay with organic remains and peaty gyttja (8050-7810 BP) reflects the widest distribution of broad-leaved trees (Ulmus, Tilia, and Quercus), alder and hazel in the area, characteristic of the Holocene Climatic Optimum (Atlantic climatic period). The pollen composition in the peaty gyttja at $1.9-1.25 \mathrm{~m}$ shows an increase in Pinus, Picea and Quercus, as well as in aquatic plant pollen (Nymphaceae, Stratiotes aloides, Menyanthes, Typhaceae). In this interval water chestnut Trapa natans pollen has been found, its presence also recorded in the depth interval 0.9-0.7 m (50904900 BP), represented by wood-grass peat showing a decrease in broadleaved tree pollen and an increase in Picea and herb pollen, including pollen of ruderals and cultivated plants, as well as in the amount of charcoal dust. The uppermost layer of the core contains pollen of cultivated plants (Hordeum, Triticum, Avena) and anthropogenic indicators Plantago major/media, Chenopodium album, Polygonum aviculare, Urtica and Rumex acetosella, dated to 4890-4670 BP and 3950-3770 BP.

\section{Outcrop at the Baltic Sea Bluff}

Organic sediment layers formed in the Sārnate area during the Holocene are nowadays being revealed due to coastal erosion. These sediment sequences can be studied at the Baltic Sea coastal bluff (Lat. N 57.0714669; Long. E 21.4155118) located between the River Vičaka to the north and the River Pāžupite to the south. The bottom interval of this outcrop is represented by sandy and silty sediment layers, which are overlain by an organic layer consisting mainly of peat in various stages of decomposition. The lowest unit, is at 3.2-3.1 m depth from the top, formed 97809630 BP (Saulite et al. 2007) and consists of well-decomposed sandy wood-grass peat, containing fragments of wood (with some charred pieces), as well as remains of grasses and Bryales. The admixture of sand decreases in the peaty gyttja further up in the section (3.1-2.8 m). This layer is rich in plant remains, including wood remains. Carex achenes and Menyanthes trifoliata seeds have been found (Figure 2). It is covered by poorly decomposed Hypnum-sedge peat with pressed structures containing Carex sp. achenes and Menyanthes trifoliata seeds (depth 2.8-2.7 m), formed 6230$6190 \mathrm{BP}$.

The layer of Hypnum-sedge peat is covered by Hypnum-reed peat $(2.6-2.7 \mathrm{~m})$, which is overlain by Hypnum peat with Menyanthes trifoliata seeds at 2.5-2.6 m depth. Conditions for plant growth changed at the depth 2.3-2.5 m, when grass-sedge peat with large numbers of Carex sp. achenes, fewer Menyanthes trifoliata seeds and some Betula nana achenes accumulated. The uppermost layer (depth: 2.3-2.2 m), consisting of well-decomposed grass peat with Carex sp. nutlets, Cladium mariscus, Menyanthes trifoliata and Potentilla seeds, as well as Betula nana achenes, is dated to 3610 $3510 \mathrm{BP}$. The overlying peat layer, at 2.2-2.0 m depth, consists of well-decomposed, dense peat with branch fragments, many Picea sp. needle fragments, and small quantities of Betula sect. Albae and Carex nutlets, Potentilla achenes, charred 
Polygonum achenes and Viola seeds. During the formation of this layer the ground water level was low and the fen became overgrown with forest. The top peat layer is covered by dune sands.

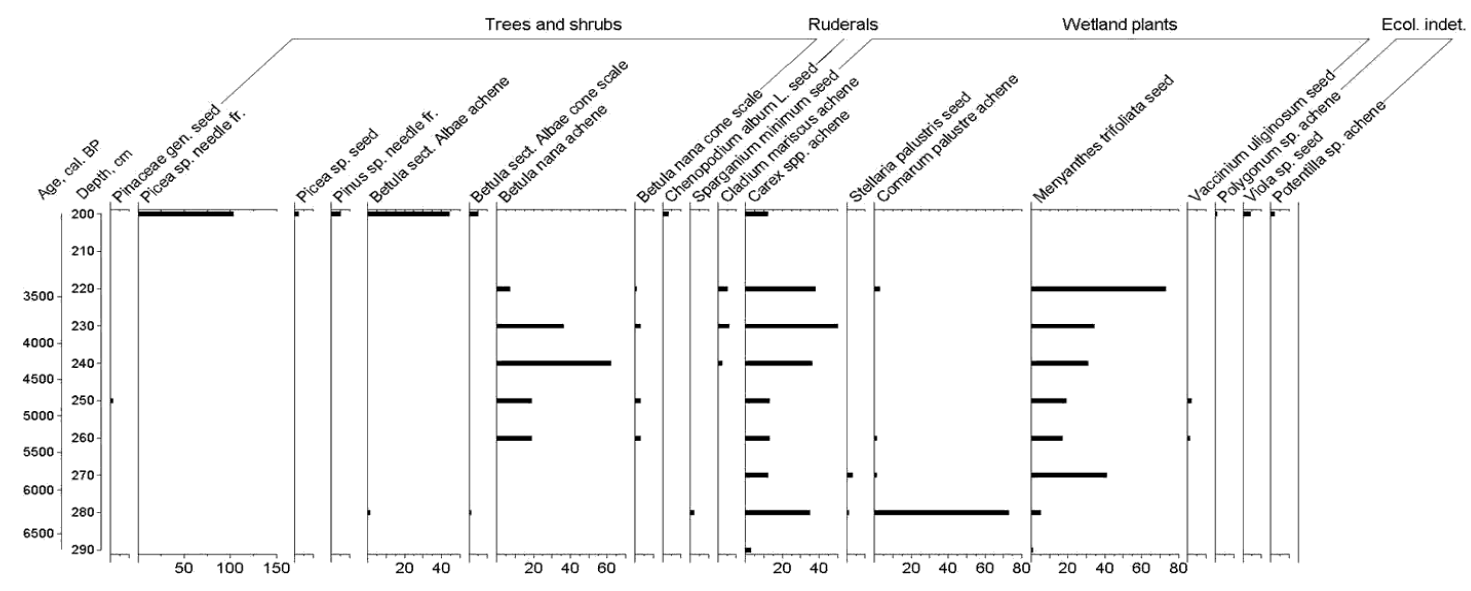

Figure 2. Plant macro-remain diagram from peat deposits of the Baltic Sea Coastal Bluff between the rivers Vičaka and Pāžupīte (authors' figure)

Plant macro-remain results are supported by pollen data from the same sediment section (Kalnina et al. 2011). The pollen analysis shows that the layer of sand is rich in plants, providing pollen spectra characteristic of the vegetation of the climatic optimum, with the highest amounts of broadleaved trees: Ulmus, Tilia and Quercus. The depth interval $2.7-2.2 \mathrm{~m}$ contains pollen anthropogenic indicators Plantago major/media, Chenopodium album, Polygonum aviculare, Urtica and Rumex acetosella, dated to 3610-3510 BP, indicating human activity in the area.

\section{Conclusions}

The shallow lagoon lake gradually became terrestrialised and in-filled with fen peat, and later also with raised-bog vegetation. The pollen data reflects vegetation development, starting with boreal pine forests in the Sārnate area, which changed to an open or mosaic landscape from the very beginning of the Holocene Climatic Optimum, before 8050-7840 BP, when substantial changes were caused by both climatic and sea-level change. The record of the Water chestnut (Trapa natans) pollen in the gyttja under the fen peat indicates that it grew there at the end of the Holocene Climatic Optimum.

Plant macro-fossil and pollen data along with archaeological evidence from the Sārnate archaeological site indicates intensive human activity in the area during the latter part of the climatic optimum and the first part of the Late Holocene (Subboreal). The sediment composition at the Sārnate site was changing: transformed from Littorina Sea lagoon to shallow lagoonal lake, this area was gradually terrestrialised and in-filled with fen peat and later also with raised-bog vegetation. The presence of cereal and weed pollen provides confirmation that agriculture was also being 
practiced, at least during the final phase of occupation, in the late 6th and the 5th millennium BP.

\section{Kopsavilkums}

Paleoǵeogrāfisko apstākḷu pārmaiṇu rakstura izpēte Sārnates bijušās lagūnas teritorijā ir saistîta ar šīs teritorijas geologísko uzbūvi un mūsdienu geolog̣isko procesu norisi, kā arī ar akmens laikmeta mītnuu izpēti šajā teritorijā. Veikta nogulumu vecuma datěšana, sporu un putekšņu izpēte IX urbumam Sārnates apmetnes teritorijā, kā arī jūras krasta atsegumā ziemeḷos no Pāžupītes ietekas jūrā. Priekšstatu par nogulumu veidošanos zemā purva apstākḷ los rada augu makroatlieku pētijumi. Oglotas ezerrieksta un citu augu makroatliekas atrastas akmens laikmeta apmetnes " $\mathrm{K}$ " mītnes un 11. mītnes pavardu nogulumu paraugos.

\section{References}

Bērziňš, V. (2008). Sārnate: living by a coastal lake during the East Baltic Neolithic. Acta Universitatis Ouluensis. B Humaniora, 86. http://herkules.oulu.fi/isbn9789514289415/ (23.02.2012).

Cerina, A., Kalniņa, L. and Bērziņš, V. (2013). Changes in the level of Lake Sārnate and the conditions for settlement along its shore during the holocene. In: Kḷaviņš, M. and Kalniņa, L. (eds.) Bog and lake research in Latvia. Riga: The University of Latvia Press, 75-80.

Dolukhanov, V.M. (1977). Holocene history of the Baltic Sea and the ecology of prehistoric settlement. Baltica, 6, 227-247.

Dreimanis, A. (1947). Pollenanalytische Datierung archaologischer Funde von Sarnate, Lettland, und die Entwicklungsgeschichte des Sarnate-Moores. Contributions of the Baltic University, 28.

Galeniece, M. (1960). Dažu Kurzemes purvu stratigrāfija un genēze. Latvijas PSR veǵetācija. 3. sēj. Rīga: LPSR ZA izdevniecība, 21-41.

Grīnbergs, E. (1957). The Late Glacial and Post-Glacial history of the coast of the Latvian SSR, Rīga.

Kalniṇa, L. and Ceriṇa, A. (2018). Biotas mainība holocēnā. In: Nikodemus, O., Kḷaviṇš, M., Krišjāne, Z. and Zelčs, V. (eds.) Latvija. Zeme, daba, tauta, valsts. Rīga: Latvijas Universitāte, 442-445.

Kalnina, L., Cerina, A. and Berzins, V. (2011). Environment and vegetation changes during the Neolithic settlement at Sarnate site, Western Latvia. XVIII INQUA Congress Bern, Switzerland. Sessions \& Abstracts.

Mūrniece, S., Kalniņa, L., Bērziņš, V. and Grasis, N. (1999). Environmental Change and Prehistoric Human Activity in West Kurzeme, Latvia. In: Miller, U., Hackens, T., Lang, V., Raukas, A. and Hicks, S. (eds.) Environmental and Cultural History of the Baltic Region. Belgium: PACT 57, 3570 .

Saulīte, A., Kalnina, L., Stinkulis, G.. and Ceriña, A. (2007). A new data from the outcrop at the coastal cliff of the Baltic sea near to Sārnate. In: Guobyte, R., Stančikaitè, M. (eds) The Quaternary of Western Lithuania: from the Pleistocene glaciations to the evolution of the Baltic Sea. Proceedings of the INQUA Peribaltic Group Field Symposium, Vilnius: Institute of Geology and Geography, 73-74.

Šturms, E. (1940). Sārnates purva mītnes. Senatne un māksla, 1, 41-64.

Vankina, L. (1970). The Bog Settlement of Sārnate. Riga: Zinatne.

Veinbergs, I. (1999). Baltijas jūras leduslaikmeta beiguposma un pēcleduslaikmeta baseinu Latvijas krasta zonas morfo- un litodinamika (pēc Latvijas piekrastes pētijumu rezultātiem). Latvijas Universitātes Ģeologijas institūts, atskaite.

Velichkevich, F.Y., Zastawniak, E. (2006). Pteridophytes and monocotyledons. In: J.J. Wojcicki (ed.). Atlas of the Pleistocene vascular plant macrofossils of Central and Eastern Europe. Krakow: W. Szafer Institute of Botany, Polish Academy of Sciences, 224.

Warner, B.G. (1990). Plant macrofossils. Methods in quaternary ecology. Geoscience Canada, 53-63. 